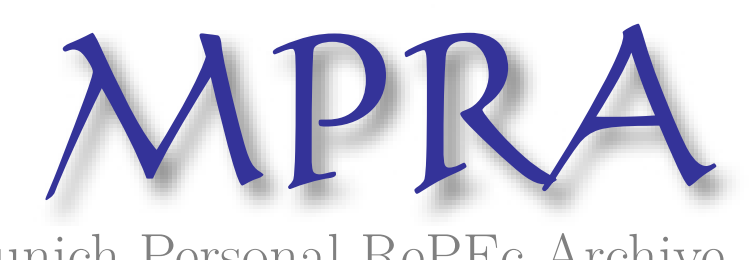

Munich Personal RePEc Archive

\title{
THE POLITICAL ECONOMY OF INTERNATIONAL FINANCIAL INSTITUTIONS' LENDING TO PAKISTAN
}

Anwar, Mumtaz

Hamburg Institute of International Economics

10 January 2006

Online at https://mpra.ub.uni-muenchen.de/5601/ MPRA Paper No. 5601, posted 05 Nov 2007 UTC 


\title{
THE POLITICAL ECONOMY OF INTERNATIONAL FINANCIAL INSTITUTIONS' LENDING TO PAKISTAN
}

\author{
MUMTAZ ANWAR*
}

\begin{abstract}
This paper analyzes the determinants of multilateral aid from international financial institutions (IFIs) to Pakistan, focusing on the world three major IFIs, the World Bank, the IMF and the ADB. Political economic factors, notably bureaucratic interests and major shareholders economic interests, are suspected to be relevant in international aid allocation decisions. Pooled Tobit estimation analyses confirm this hypothesis. Although recipient need also proves to be a relevant determinant of lending, bureaucratic interest outranks the former. Among the main multilateral donors, the IDA and the ADB are shown to be more bureaucratic and stakeholders economic interest-oriented in their lending decisions than the IBRD and the IMF, which tend to adhere to official lending explanations.
\end{abstract}

\section{INTRODUCTION}

A growing amount of literature on political economy suggests that multilateral lending decisions are based on political economic factors in which donor interest prevails more than recipient need. In particular, international bureaucracy and its utility maximizing behaviour are generally considered to

\footnotetext{
*The author is Research Fellow at Hamburg Institute of International Economics (HWWI), Germany, and Assistant Professor of Economics at the University of the Punjab, Lahore (Pakistan).

E-mail: mumtaz.anwar@pu.edu.pk
}

The author wishes to thank Katharina Michaelowa for guidance, many valuable comments and suggestions, and Axel Borrmann and Jennifer Plaul for additional comments. Financial support provided by the University of the Punjab, Lahore (Pakistan), is gratefully acknowledged. 
play a major role. The corresponding line of argument strongly leans on the economic theory of bureaucracy (Niskanen, 1994; Moe, 1997; Wintrobe, 1997; Borcherding and Besocke, 2002; Michaelowa, 2003). Internal career structures and future prospects of obtaining better positions in their home countries governments provide an incentive to the bureaucrats working at multilateral financial institutions to disburse money to their home countries. Moreover, the major shareholder countries' economic and political interests and the respective countries' voting power at IFIs, are also considered as the major determinants of lending to the developing countries (Fleck and Kilby, 2006; Andersen et al., 2005, 2006).

This paper applies a political economic analysis of decision making to major IFIs' lending to Pakistan. The IFIs most relevant for Pakistan since 1960 are the World Bank, the International Monetary Fund (IMF) and the Asian Development Bank (ADB). During the second half of the $20^{\text {th }}$ century, these IFIs provided both financial support and policy advice to Pakistan. In 2002, Pakistan ranked second among the recipients of International Development Agency (IDA) lending commitments (concessional window of World Bank lending). In addition, during the same year, Pakistan was also the second largest recipient, following India, of ADB loans, receiving US \$ 1.14 billion (20.1\% of ADB's total lending). The World Bank (2004a) justifies its important financial support to Pakistan by stating that, "it is primarily a reflection of Pakistan's progress in a number of key areas of reform." The IMF resumed its lending to Pakistan in 2000, after certain break-downs and suspensions.

Stone (2004) notes that neither of the IMF's lending decisions had anything to do with Pakistan's domestic economic management, which continued to be poor. Furthermore, it has been frequently noted that although Pakistan did not comply with IMF conditionalities and World Bank targets, new arrangements were still concluded (Hasan, 1998; Raman, 2000).

At the same time, as observed by Barro and Lee (2002), Pakistan was among the five developing countries which had the highest number of professional staff at the IMF in 1999. There is also some evidence that Pakistani nationals working with the IMF or other IFIs obtained top positions in their home government later on.

This creates some doubts about the actual objectives of IFIs' lending decisions and raises some questions which should be further explored: Why did IFIs extend lending to Pakistan over last four decades? Was IFIs' lending to Pakistan based on economic need, on previous performance of Pakistan's economy, or could it be explained by bureaucratic interests? Can the decision 
making process in IFIs be influenced by a higher percentage of voting power within these institutions?

In order to answer these and similar questions, we analyze the empirical evidence of World Bank, IMF and ADB lending to Pakistan over time. As far as the World Bank is concerned, we distinguish between the IDA and the International Bank for Reconstruction and Development (IBRD), because the voting power of their shareholder countries on the executive boards is different for the two institutions. Previous empirical studies, such as that of Barro and Lee (2005), test similar questions using a cross-country analysis for a single institution, namely, the IMF. They find that loans tend to be larger and more frequent when a country has a bigger quota and more professional staff at the IMF, or when a country is more closely connected politically and economically to the major shareholding countries of the IMF. In this study, the analysis will be carried out across institutions but for a single recipient country. This approach has the advantage that potential differences in the incentive structures of different donor institutions can be examined. Moreover, looking at only one recipient allows us to follow the development in this particular country in more detail, and to consider our econometric analysis in the context of specific national developments.

The study is divided into four parts. Section II provides a brief overview of IFIs' lending practices to Pakistan. In section III, hypotheses about the determinants of political decision making in these IFIs will be presented, and regression results for both the probability of obtaining loans and the size of these loans will be discussed. In this section, we will also present the results for each donor and compare the differences between them. The conclusions will be presented in section IV.

\section{IFI'’ LENDING TO PAKISTAN: THE EVIDENCE}

International financial institutions have played a major role in providing large amounts of lending to Pakistan over the last fifty years. According to data provided by the OECD's Development Assistance Committee (DAC) on total official flows, a total amount of US \$ 28 billion in multilateral aid flows was disbursed to Pakistan from 1960-2002. More than $82 \%$ of these multilateral official flows came from three major international financial institutions, namely, the World Bank, the Asian Development Bank and the IMF (OECD/DAC, 2005).

Among these, the World Bank (IBRD and IDA) was the largest source of multilateral flows to Pakistan, providing half the total resources. Pakistan 
joined the World Bank in July 1950. Since 1952, according to the World Bank (2004b) Country Brief, the World Bank has approved 85 loans and 125 credits for Pakistan, totaling more than US $\$ 14.3$ billion. In May 2005, the World Bank announced another package of US \$ 4.5 billion to Pakistan for three years, which will enhance its annual lending to Pakistan from about US $\$ 900$ million to US $\$ 1.5$ billion. In sum, Pakistan is among the top ten recipients of World Bank lending. However, World Bank lending to Pakistan has fluctuated over time. After the year 1990, Pakistan received the lowest amount of total official flows from the World Bank (US \$ 300.8 million), in the year 2000. Then, suddenly, in 2001, World Bank lending to Pakistan increased to US \$ 669.17 million. Further, in the year 2002, Pakistan was second among the top ten recipients of high commitments from the IDA. Finally, with even higher disbursements than commitments (US \$ 961.1 million) in 2002, Pakistan became highest recipient of World Bank lending.

The Asian Development Bank has been the second largest source of multilateral financing to Pakistan, following the World Bank. Since 1968, Pakistan has received more than US $\$ 12.6$ billion in loans from the ADB, making it the second largest borrower, after Indonesia. At the end of 2001, ADB funding to Pakistan increased by $148 \%$ from the previous year to US $\$$ 957 million. In 2002, the country further received more than US \$ 1 billion and became the top client of the ADB concessional lending window from the Asian Development Bank fund (ADBf).

The bulk of this lending from the World Bank and the ADB, especially in the last two decades, occurred under various structural adjustment programmes and to support Social Action Programmes. Loans given towards structural adjustment programmes were predefined for reforms in the financial sector, tax system, public utilities and public expenditure, in order to reduce trade and budget deficits. However, Hasan (1998) observes that although macroeconomic imbalances remained high above the agreed goals and showed little signs of improvements, World Bank lending actually increased during 1990s. In addition, a sizable portion of this lending was in the form of relatively quickly disbursed policy lending in contrast to lending for specific projects. Although projects like the Social Action Programme Project I (SAPP-I), launched in 1992 to improve the delivery of social services in primary education, basic health care, family planning and rural water supply showed disheartening results, financing of the SAPP-II by IFIs continued in 1996. Foreign donors, under the leadership of the World Bank and Pakistan itself, spent US \$ 8 billion on the Social Action Programme project, but data seems to indicate that the SAPP has failed (Easterly, 2003). 
The third multilateral source of finance, the IMF, entered into different agreements with Pakistan after 1988. ${ }^{1}$ Since that time, Pakistan has been a prolonged user of IMF resources. Lending from the IMF was aimed at providing medium term balance of payment assistance under different facilities, yet in practice, it served almost the same long-term development purposes as those resources provided by the World Bank and the ADB.

Although Pakistan has not experienced smooth relations with the IMF, it remains the top client of the IMF among developing countries. During the period of 1988-2000, out of a total agreed amount of IMF loans of US \$ 4.07 billion, only US $\$ 2.10$ billion (51.5\%) was actually disbursed to Pakistan. This was due to Pakistan's poor track record of policy implementation. Nonetheless, old IMF arrangements were continuously followed by new arrangements, and the same unmet conditionalities were continuously repeated.

As reported by the IMF independent evaluation office (2002), Pakistan may be the classic example to suggest that the decision making process of the IMF since the 1980s has been politically driven to a large extent. Personal contacts also appear to play a major role. In fact, at different points in time, talks resumed and arrangements were concluded with the IMF and the World Bank when the governments of Pakistan directly included highlevel staff from these institutions. Mahbubul Haq, former Director of the World Bank, was the Finance Minister of Pakistan in 1988, Moeen Qureshi, Senior Vice-President of the World Bank was caretaker Prime Minister of Pakistan in 1993, and Shahid Javed Burki, Vice-President of the World Bank, was Finance Minister of Pakistan in 1994 and 1996. In 1988, 1993 and 1996, this coincided with new lending arrangements.

It appears that more than merely development or economic considerations drive the major IFIs' lending to Pakistan and thereby, to a large extent, the overall multilateral lending received by this country. IFIs' lending through structural adjustment programmes, sectoral lending and lending for economic reform in the last two decades and earlier casts some doubts on the relevance of officially stated lending policies, which emphasize economic need and policy performance (merit). Thus, IFIs' lending to Pakistan will be examined in more detail in the following section, with special attention to the interests of the different actors within these institutions.

\footnotetext{
${ }^{1}$ Pakistan entered into its first agreement with the IMF in 1958, but the amount was not determined, and no further substantial agreement was made until 1988.
} 


\section{THE POLITICAL ECONOMY OF IFIs' LENDING TO PAKISTAN}

It is already widely accepted in the literature that an appropriate model to explain lending decisions should be comprehensive and take into account the potential effect of both donor interest and the recipient's need and merit. This section will explain this 'hybrid' model, in which multilateral donors' interests can be accounted for by the bureaucratic inertia and political interest of the multilateral organizations. As discussed in section II, the bureaucratic interest of IFIs could have an influence on lending decisions to Pakistan. Barro and Lee (2005) find some evidence for this hypothesis when analyzing IMF lending to a large set of countries. This approach is based on economic models of bureaucracy, in which bureaucrats disburse money in order to maximize their own utility (Easterly, 2002). Moreover, donor governments within IFIs have their own preferences and often attempt to use IFIs for their own purposes (Fleck and Kilby, 2006; Dreher and Jensen, 2003; Andersen et al., 2005). With this in mind, while considering IFIs' lending to Pakistan, we view IFIs as bureaucratic and political institutions which maximize the utility of their stakeholders, i.e. of bureaucrats and major shareholder countries.

\section{DETERMINANTS OF IFI'' LENDING DECISIONS: SOME THEORETICAL HYPOTHESES}

The motives of lending which directly correspond to IFIs' openly declared objectives can be described in two different sets of variables. The first determines the needs of recipients, and the second captures their "merits", i.e. their previous efforts to establish a sound economic policy environment (Berthélemy, 2006; Cline and Sargen, 1975).

With respect to economic needs, we should generally consider that, under the given economic conditions, Pakistan falls into the category of a low income country, reaching a per capita gross national income of only US \$ 520 in the year 2003 (World Bank 2004b). This is far below the IDA established lending threshold of US \$ 865. A large part of the country's population, almost 33 percent, is facing absolute poverty, as measured on the basis of the national poverty line. Poverty rates fell during the 1980s and early 1990s, but started to rise again towards the end of the 1990s. In addition, over last few decades, Pakistan's economy has faced many serious economic problems, on both internal and external economic fronts. In these situations and throughout the 1970s and the late 1990s, the country was clearly in need of foreign resources. According to the objectives initially 
defined by multilateral financial institutions for distributing loans, and as taken up by Frey and Schneider (1986) for the World Bank and Barro and Lee (2005) for the IMF, IFIs' lending should be based on the economic needs of a country. Thus, Pakistan should have received more lending from international organizations in those times when it faced particular economic hardship, as concluded in our first testable hypothesis:

\section{Hypothesis 1: IFIs' lending to Pakistan is positively related to the country's economic needs}

We now come to the aspect of "merit", which is typically referred to in terms of "good governance". Good governance is a multifaceted concept, and both the economic and the more general political dimension are relevant here. As a first step, let us consider economic governance. According to official development policy lending strategies, the implementation of economic and social policies that promote growth is another basic criterion for IFIs' loan allocation. The World Bank and IMF joint strategy papers state that development policy lending is normally undertaken only in a country that has an adequate macroeconomic framework in place. Therefore, lending should contain positive incentives, and good performance should be rewarded with more lending from IFIs (Cline and Sargen, 1975; Burnside and Dollar, 2000). Although Pakistan is a poor country, the economy showed an impressive economic performance during the 1980s and early 1990s. Conversely, in the 1970s, economic performance was very poor, and it also slowed down again considerably in the late 1990s, due to imprudent policies, which resulted in a rather inconsistent pattern of growth. These variations should be expected to find their reflection in IFIs' lending. This leads us to formulate our second hypothesis:

\section{Hypothesis 2: IFIs' lending to Pakistan is positively related to an improved performance of the country's economy}

While Hypothesis 2 covers economic governance, we now move on to political governance, which constitutes the other merit-based criterion for IFI lending. Strong arguments can be made that good political governance indirectly influences economic growth and leads to reduce poverty (Rodrik 2003). If this is true, we should expect IFIs to take into account not only economic, but also political governance when making their lending decisions. However, previous studies on IMF and World Bank lending do not find much evidence for a relationship between political governance indicators and lending decisions (Bird and Rowlands, 2001; Barro and Lee, 2005; Kilby, 2006). Pakistan, which has experienced different types of 
governments, weak political institutions and many periods of low government effectiveness, represents an interesting additional testing ground for whether political governance has had any effect on IFIs' lending decisions. This leads us to our third hypothesis:

Hypothesis 3: IFIs' lending to Pakistan is positively related to good political governance

So far we have only considered the development policy, or need and merit oriented motives of IFIs' lending. Let us now turn to the political economic motives of IFIs' lending to Pakistan. We assume that, concerning lending decisions to developing countries, IFIs must be understood as both bureaucratic and political organizations. The bureaucrats working in these institutions can be expected to lobby for decisions and lending in favor of their home economies, so that they can get better positions in their respective home governments later on. Any decision in favor of their country, including higher lending to their country, will add to their own utility (Frey and Schneider, 1986; Barro and Lee, 2005). Thus, bureaucrats at multilateral organizations have an incentive to disburse money to their home countries, even if their home countries have not complied with previous targets and conditionalities (Mosley et al., 1991; Dreher, 2004). As pointed out in section I, there have been several instances in which Pakistan did not comply with IFIs' conditionalities, but still received new funding. Simultaneously, we observe significant changes in Pakistan's representation in IFIs' major decision making bodies.

According to the political economic literature cited above, it can be assumed that any position of power held by national bureaucrats in international organizations will be used to obtain more loans for their own country, and ultimately to maximize their own individual utility. This leads us to formulate our fourth hypothesis:

Hypothesis 4: The higher the number and the stronger the bureaucratic power of Pakistani nationals at IFIs, the higher the probability of Pakistan receiving more and larger loans

Another political economic motive for distributing resource, also related to bureaucratic interest, could be what Birdsall et al. (2003) describe as "defensive lending". The idea is that loans with a high probability of default are followed by new loans, so that the latter ensure the repayment of the former. Accordingly, when debt burdens grow, lending may increase. In fact, for the international bureaucracy, avoiding default is very important as it would do harm to their image as a competent decision making body. 
Moreover, lending in general, even to countries which have already accumulated high debt burdens from prior lending, is consistent with the general bureaucratic objective of maximizing the overall flow of resources. This resource flow is in turn related to the overall budget of their organization, and thus indirectly to bureaucrats' pay and prestige (Vaubel, 1991).

Birdsall, Claessens and Diwan (2003) show that countries with higher debt, especially those indebted to international organizations, have indeed received larger net transfers than other countries. Based on the data on external debt and resource flows to Pakistan, it appears that Pakistan's debt stock has grown very rapidly in the last three decades. The IDA total outstanding debt alone grew 5 times over the period from 1983 to 2003 (World Bank, 2004). Anecdotal evidence suggests that in 1999, Pakistan was close to default when the IMF resumed its lending. The arguments with respect to defensive lending are summarized by our next hypothesis:

\section{Hypothesis 5: The higher Pakistan's debt to IFIs, the higher the probability for new lending and a higher volume of lending}

Another common perception in the political economics of international organizations is that IFIs serve the economic and political interests of their major shareholders (Stone, 2004; Fleck and Kilby, 2006; Kilby, 2006). Thus, any country that has close economic and political ties with the major shareholders (e.g. the US and Japan) of multilateral organizations will be more likely to receive loans from IFIs, and the size of the loans is likely to be larger. The US and Japan can exert pressure on IFIs in different ways, particularly through their executive directors on the board, who have the maximum number of votes. Specifically, at the IMF, some important decisions require more than $85 \%$ of the votes. In this case, Japan and the US alone can block lending decisions. Pakistan has gone through different phases of political and economic relations with these countries. Particularly, relations with the US worsened after the imposition of sanctions under the Pressler Amendment at the US senate. ${ }^{2}$ We expect that IFIs' lending to Pakistan depends on variations in the country's bilateral economic and political relationships with major shareholder countries. We capture this in our final hypothesis:

\footnotetext{
${ }^{2}$ The Pressler Amendment passed in the US Senate in 1985 requested the US President to personally certify that there would be no risk of nuclear arms development in Pakistan. Without this certification, no more aid could be committed to this country.
} 
Hypothesis 6: Closer economic links between Pakistan and the US and/or Japan, or higher political or strategic relevance of Pakistan for these countries will increase Pakistan's chances of obtaining more and higher loans from IFIs

Overall, along with considerations of the country's need and merit, we retain bureaucratic interests as well as US and Japanese economic interests as potential determinants of IFIs' lending to Pakistan.

\section{EMPIRICAL ANALYSIS OF IFIs' LENDING TO PAKISTAN OVER TIME}

In order to empirically test these hypotheses we adopt the Tobit econometric estimation method, used recently in most aid allocation studies. The advantage of such an approach is that we can take into account the censored nature of gross total official flows from IFIs to Pakistan over time. This method estimates the aid flows in one step and is appropriate if the exogenous variables can be expected to have the same impact on the probability of receiving aid and on the amount of aid allocated thereafter (Gang and Lehman, 1990; Berthélemy and Tichit, 2004).

The gross disbursement of total official flows to Pakistan relative to the total flows to developing countries (TOFDev) and to low-income countries (TOFLic) were taken from OECD/DAC (2005) data as the dependent variables, in order to analyze IFIs' lending decisions to Pakistan. Using disbursements rather than commitments reflects the actual spending of aid funds, and using gross as opposed to net flows avoids the consideration of those debt repayments which are carried out under the authority of the recipient rather than the donor country. Given the focus of our study, Pakistan's share of aid as compared to aid received by other developing countries emerges as a natural choice for the dependent variable, rather than the level of aid or aid per capita. It captures the relative importance of the country as compared to other recipients of multilateral aid flows. Crosscountry studies which also include middle and higher income countries, such as those by Trumball and Wall (1994), Fleck and Kilby (2006) and Kilby (2006), only use the share of aid relative to lending to all developing countries. However, as we are only considering Pakistan, which is a lowincome country, its share of aid receipt among low-income countries could be a relevant alternative indicator. Taking into account both alternatives could be important especially if we assume that there might be predefined overall amounts for specific country groups such as low-income countries. Note, for instance, that only the latter are eligible for IDA loans at all. Each 
institution is considered in the panel, starting from the year in which its lending to developing countries was established. The IBRD, IDA, ADB and IMF established their lending in 1952, 1961, 1968 and 1977 respectively. However, data on the IBRD's lending to Pakistan is only provided by the OECE from 1960 onwards.

To examine Pakistan's economic need and merit in relation to IFIs' lending decisions as addressed in hypotheses 1 to 3, we require information on economic variables related to economic need and performance. The most direct indicator of any country's need for international aid flows is per capita GDP. Moreover, other studies on IFIs' lending decisions, i.e. those by Bird and Rowlands (2001) and Frey and Schneider (1986), also suggest using current account and government budget deficits as indicators of internal and external economic strains. Therefore, to measure the economic needs of Pakistan's economy, we use the data on per capita GDP (GDPPC), current account deficit as a percentage of GDP (CurrentAcDef), and the overall budget deficit as a percentage of GDP (BudgetDef), from the World Development Indicators (World Bank 2004c). For detailed definitions of variables and their sources, see Anwar (2006).

To determine the performance of Pakistan's economy, the annual GPD growth rate $(G D P g)$ was taken as the indicator variable. Higher GDP growth indicates better economic performance. The data is again taken from the World Bank (2004c). The GDP growth rate as well as all other economic variables for determining IFIs' lending to Pakistan were used with a oneperiod lag, as fully updated information is generally not available for decision making, even for international institutions.

In order to measure good political governance, previous studies (see Barro and Lee, 2005) use the rule of law and democracy. However, Mosley, Harrigan and Toye (1991) argue that political stability, i.e. in particular the frequency of change in government, might be a preferable indicator for political governance. This may be true in particular for early years in which comprehensive indicators on democracy and the rule of law were not available. The Kaufmann, Kraay and Mastruzzi (2005) governance indicators were computed only in 1996, and even the Freedom House index on political rights and civil liberties has only existed since the early 1970s. Thus, we try to capture political governance here by looking at political instability (PolInstab), which allows us to compute the required time series starting from 1960.

Political instability measured in terms of changes in government is well adapted to Pakistan, because changes in the Pakistani government before 
completion of tenure have been frequent. In our calculations, any change in the Pakistani government in a particular year is assigned a 1 , while a 0 represents no changes. Taking a moving average of five year periods, we establish an index on a scale from 0 to 1 . A value closer to 1 indicates a higher number of government changes, i.e. higher political instability. The data for changes in government was taken from the Polity IV Project (2002).

It would have also been interesting for our analysis to have information on the number of Pakistani professional and managerial staff at each institution, in order to measure the effect of bureaucratic pressure and lobbying behaviour of these bureaucrats on IFIs' lending to Pakistan. Unfortunately, however, there is no such data available from the IFIs, and where it is available, for example from the IMF Diversity Office, it is only for very short periods of time. Thus, alternatively, we used the Pakistani executive director voting power $\left(P k \_e d \_v p\right)$ as a percentage of total voting power of all the executive directors on the board. This data was taken from the annual reports of the World Bank, ADB and IMF (World Bank, ADB and IMF annual report, Various Years). This variable takes into account the Pakistani national executive director, or alternative executive director, representing Pakistan and the group of countries by whom he was elected to the executive board of IFIs. In the case of a temporary Pakistani alternative executive director at the IMF, we multiplied voting power by 0.5 , in order to weigh down the position relative to full power. To further explain the bureaucratic interests of IFIs' lending, the information on Pakistani nationals working in top positions, including vice presidents and directors, was gathered from the annual reports of the World Bank, ADB and IMF. The numbers of Pakistani top officials ( $P k \_o f f$ ) were taken as the percentage of total officers of each institution. Vacant posts were not taken into account while compiling the data.

We consider Pakistan's debt to all multilateral institutions as a percentage of total debt (MultiDt), in order to test our fifth hypothesis. The variable is used with a one-period lag, considering that the decision making process at IFIs takes some time. The data is taken from Global Development Finance (World Bank 2004d).

Finally, the economic interests that major shareholders of IFIs may have in Pakistan, as a factor of determination of the IFIs' lending to Pakistan (as suggested in Hypothesis 6), is measured by the trade intensity of the US and Japan with Pakistan. Trade intensity of Pakistan with the US (USTrade) and Japan (JPTrade) is reflected by bilateral trade (exports + imports) between 
Pakistan and these countries, expressed as a ratio of Pakistan's GDP. The data was taken from the IMF (IMF-Directions of Trade Statistics 2004).

In order to capture the political interests related to lending of the IFIs' major shareholders, we included various dummy variables, in particular a dummy for 1985, the year in which the Pressler Amendment was passed in the US Senate, and a dummy (dummy01-02) for the years 2001 and 2002, to capture the post September $11^{\text {th }}$ effect on aid allocation to Pakistan. In some studies on IMF and IDA lending, US political interest is reflected by voting behaviour in the United Nations General Assembly. In line with this, we include Pakistan's political proximity to the US, measured by voting in the UN General Assembly. We also take into account bilateral aid from major shareholder countries as additional variables. In order to test IFIs' response to international crises, such as the Latin American debt crises and Asian crises, and their effects on IFIs lending to Pakistan, we also introduce dummies for the early 1980s and the late 1990s, respectively.

Table 1 presents the results of our regression analysis. We use both an overall pooled Tobit model and a Tobit model with IFI specific random effects. The latter was also adopted by Berthélemy and Tichit (2004) and Barro and Lee (2005).

Fixed effects cannot be considered as a relevant alternative. They lead to inconsistent estimates because they cannot be estimated based on the total number of observations but only on the (rather limited) number of observations for different points in time within each institution. This creates estimation problems for Probit models, as they rely on large sample properties, and consequently for Tobit models as well. ${ }^{3}$ Regressions 1 and 2 show IFIs' lending to Pakistan relative to lending to other low-income countries (TOFLic). The following four regressions present the results of IFIs' lending to Pakistan relative to all developing countries (TOFDev). Between regressions 1 and 2, and 3 and 4, model specifications differ only with respect to the inclusion of random effects for individual IFIs. Regression model 3 is then further enlarged to include trade with the US and Japan (regressions 5 and 6), political instability and a dummy for the September $11^{\text {th }}$ effect (regression 6 only). In addition, regression model 6 was also estimated with random effects, but since results remained virtually unchanged, this specification was not included in Table 1. All models were

\footnotetext{
${ }^{3}$ For a detailed discussion of this problem, generally referred to as the incidental parameters problem, see Greene (2004).
} 
also estimated including the additional variables discussed above (US policy dummy for the Pressler Amendment and bilateral aid), but as they neither turned out to be significant nor changed the results in any relevant way, we decided to exclude them from the presentation.

TABLE 1

Regression Results for IFIs' Lending to Pakistan

\begin{tabular}{|c|c|c|c|c|c|c|c|c|c|c|c|c|}
\hline & \multicolumn{2}{|c|}{ Regression 1} & \multicolumn{2}{|c|}{ Regression 2} & \multicolumn{2}{|c|}{ Regression 3} & \multicolumn{2}{|c|}{ Regression 4} & \multicolumn{2}{|c|}{ Regression 5} & \multicolumn{2}{|c|}{ Regression 6} \\
\hline & \multicolumn{2}{|c|}{ Tobit } & \multicolumn{2}{|c|}{$\begin{array}{l}\text { Random } \\
\text { Effects }\end{array}$} & \multicolumn{2}{|c|}{ Tobit } & \multicolumn{2}{|c|}{$\begin{array}{l}\text { Random } \\
\text { Effects }\end{array}$} & \multicolumn{2}{|c|}{ Tobit } & \multicolumn{2}{|c|}{ Tobit } \\
\hline & \multicolumn{2}{|c|}{ TOFLic } & \multicolumn{2}{|c|}{ TOFLic } & \multicolumn{2}{|c|}{ TOFDev } & \multicolumn{2}{|c|}{ TOFDev } & \multicolumn{2}{|c|}{ TOFDev } & \multicolumn{2}{|c|}{ TOFDev } \\
\hline & Est. & p-val. & Est. & p-val. & Est. & p-val. & Est. & p-val. & Est. & p-val. & Est. & p-val. \\
\hline \multicolumn{13}{|l|}{ Recipient need } \\
\hline GDPPC & $\underline{-0.16}$ & 0.00 & $\underline{-0.15}$ & 0.00 & -0.04 & 0.03 & $-\mathbf{0 . 0 3}$ & 0.03 & -0.04 & 0.01 & -0.02 & 0.41 \\
\hline CurrentAcDef & 1.20 & 0.14 & 1.22 & 0.13 & 0.27 & 0.39 & 0.29 & 0.29 & 0.32 & 0.38 & 0.22 & 0.58 \\
\hline BudgetDef & -1.58 & 0.25 & -1.59 & 0.24 & -0.24 & 0.65 & -0.24 & 0.61 & -0.49 & 0.35 & -0.52 & 0.35 \\
\hline \multicolumn{13}{|l|}{ Recipient merit } \\
\hline GDPg & -0.65 & 0.49 & -0.69 & 0.46 & -0.02 & 0.96 & -0.09 & 0.78 & -0.29 & 0.45 & -0.55 & 0.18 \\
\hline PolInstab & & & & & & & & & & & 11.12 & 0.11 \\
\hline \multicolumn{13}{|c|}{ Bureaucratic interest } \\
\hline Pk_ed_vp & 4.57 & 0.00 & 3.80 & 0.11 & $\underline{1.88}$ & 0.00 & 0.63 & 0.05 & $\underline{1.91}$ & 0.00 & 1.92 & 0.00 \\
\hline Pk_off & 0.68 & 0.50 & 0.44 & 0.70 & -0.11 & 0.76 & -0.61 & 0.08 & -0.11 & 0.77 & -0.12 & 0.73 \\
\hline MultiDt & 0.74 & 0.09 & 0.75 & 0.08 & 0.16 & 0.33 & 0.16 & 0.29 & 0.21 & 0.19 & -0.07 & 0.76 \\
\hline \multicolumn{13}{|c|}{ Bilateral donor interest } \\
\hline USTrade & & & & & & & & & 0.52 & 0.67 & -0.43 & 0.75 \\
\hline JPTrade & & & & & & & & & 1.59 & 0.03 & 1.47 & 0.07 \\
\hline dummy01_02 & & & & & & & & & & & 1.66 & 0.64 \\
\hline constant & $\underline{49.98}$ & 0.00 & $\underline{51.80}$ & 0.00 & 11.66 & 0.07 & $\underline{18.72}$ & 0.00 & 7.64 & 0.35 & 10.07 & 0.23 \\
\hline $\mathrm{N}$ & 104 & & 104 & & 104 & & 104 & & 104 & & 104 & \\
\hline Censored Obs. & 14 & & 14 & & 14 & & 14 & & 14 & & 14 & \\
\hline LR/Wald Chi ${ }^{2}$ & 52.16 & 0.00 & 20.22 & 0.00 & 47.81 & 0.00 & 15.49 & 0.03 & 52.62 & 0.00 & 55.53 & 0.00 \\
\hline
\end{tabular}

Notes: Italic indicates significance at the $10 \%$ level. Bold indicates significance at the 5\% level. Bold underlined indicates significance at the $1 \%$ level. For a detailed description of the variables and their sources, see Anwar (2006).

As could be expected, per capita GDP has a significant negative effect in all the regressions except regression 6, where the effect is negative but not 
significant. The estimated coefficient implies that, ceteris paribus, a low per capita GDP in Pakistan will raise the probability and volume of IFIs' lending to Pakistan. In contrast, the other variables representing Pakistan's economic need, i.e. current account and budgetary deficits, are not significant in any of the regressions presented in Table 1. All in all, these results provide only partial evidence for Hypothesis 1.

It should be noted, however, that the interpretation of the effect of the current account and budget deficit may be ambiguous. On the one hand, high deficits indicate a strong need for external resources, but on the other hand, they can be the result of bad economic policy. If IFIs react partially in response to need, and partially in response to merit, the overall sign of the coefficients is undetermined, and the coefficient estimate will only be significant if one consideration clearly dominates. To a certain extent, this ambiguity also arises with respect to the interpretation of the coefficient of GDP growth. However, as we have included GDP per capita separately, the objectives of reacting to need on the one hand, and rewarding good economic performance on the other hand, are more easily separable here.

The estimated coefficient of the annual GDP growth rate shows a negative sign, but does not appear to be significant in any of the regressions. This implies that our data do not give any support to hypothesis 2, i.e. a positive relationship between IFIs' lending to Pakistan and the performance of Pakistan's economy. If we were to interpret this insignificant coefficient at all, the negative sign shows that higher growth may reduce rather than increase lending from the IFIs.

Results for good governance represented by political stability in regression 6 do not confirm our initial hypothesis either. While the coefficient is not fully significant ( $\mathrm{p}$-value $=11 \%$ ), it shows a positive sign, indicating that if a relationship exists at all, frequent change in the government, and hence more political instability, seems to be rewarded rather than penalized by IFIs.

In comparison with the need and merit variables, the IFI interest variables and the variables for shareholder interest appear to be more significant in our regression results. The bureaucratic interests measured by the Pakistani executive director voting power at each institution are significant in all but one regression and close to significant, at least at the 10 percent level, even there. We thus find evidence for a robust link between the power exercised by bureaucrats and lending to their home countries. The other variable ( $P k \_$off) representing the lobbying behaviour of Pakistani national bureaucrats at IFIs in support of more lending for Pakistan, is not significant in our models presented in Table 1. This could be due to the fact 
that, as opposed to the political staff, i.e. the executive directors, the administrative staff does not consider their home country's relative position, but simply argues for higher funding for their country, whatever the situation for other countries may be. Nevertheless, administrative staff clearly does not directly make lending decisions, but only indirectly influences decision making through lobbying at the executive board, whenever there is a higher chance of achieving decisions in favor of their country. Moreover, the professional staff under their responsibility generally prepares the relevant policy papers and meeting documents, giving them a certain agenda setting power as well. As pointed out by Barro and Lee (2005), it is also possible that certain bureaucrats provide insider information to their home countries. Thus, international bureaucrats can play an indirect role in IFI lending to their countries of origin. Unfortunately, as we do not have information on the number of all administrative officers, but only on top officials, the overall effect might be quite imprecisely estimated in our regressions.

We observe that Pakistan's debt to multilateral institutions as one of the determinants of lending becomes significant in the first two regressions, with the expected positive sign. This provides some evidence of defensive lending, i.e. of IFIs' attempt to ensure the repayment of their previous loans by awarding new loans. However, this statement should be interpreted with caution, since the variable (MultiDt) loses its significance in the regressions where lending to Pakistan is taken as a percentage of lending to all developing countries. With this in mind, we have only limited support for our fifth hypothesis.

The results of regressions 5 and 6 show that Japanese trade is positively and significantly related to IFIs' lending to Pakistan, while this is not the case for US trade. This implies that IFIs' lending to Pakistan is more closely linked with Japanese economic interests than with those of the US. One reason might be that US interests in Pakistan - as far as channeled through international organizations - is of a more geopolitical and strategic, rather than economic nature. Anecdotal evidence suggests the relevance of US political interests for IMF and World Bank decisions. The data shows that lending to Pakistan by IFIs jumped after Pakistan joined the US-led coalition against terrorism following September $11^{\text {th }}$, 2001 (Calomiris, 2000; Economist, 2001). Trying to capture this by a dummy variable taking the value of 1 from 2001 onwards, does not, however, lead to any significant results. As we will see later, this can be explained by the strongly varying reactions of different IFIs in this respect. As already mentioned above, other indicators of bilateral shareholders' political interest, i.e. the dummy for the Pressler Amendment, political proximity with the US measured by voting in 
UN General Assembly and the volume of bilateral aid, were not found to be significant in any regression specification (for additional specifications, contact author). It should be noted, however, that political interest is extremely difficult to capture, so that insignificance of these results may be related, at least to some extent, to the weak indicators at hand. Additional dummy variables in response to international crises, such as the Latin American debt crises of the 1980s and the Asian financial crises in to the 1990s, do not turn out to be significant either. Apparently, Pakistan's relative position as a recipient of IFIs' aid, thus, remained largely unaffected by these economic shocks.

Overall, the results are plausible, and support the idea that bureaucratic interests are at least as important as considerations of recipients' needs or merit in determining IFIs' lending to Pakistan. With the data at hand, hypothesis 1 , regarding country need considerations, finds some support, but it loses its relevance in the full model (specification 6). There is no significant evidence for hypothesis 2 , on a positive relationship between lending and good economic performance. Hypothesis 3, regarding country merit and measured in terms of political stability, can be rejected. At the same time, hypotheses 4 and 5, on the role of bureaucracy, find clear support, and hypothesis 6, on the economic interests of major shareholders of IFIs, finds some positive support for Japan, although the result is less strongly significant than in the case of bureaucratic interests. Thus, IFIs' bureaucratic interest and bilateral donor interest appear to be the most relevant determinants of IFIs' decision making on lending to Pakistan.

\section{COMPARISON AMONG IFIs}

In the previous section we assumed that all IFIs behave in the same way when lending to Pakistan. However, Willett (2001) points out that while there has been an increasing overlap of the activities of the World Bank and IMF over time, there is still a significant difference between the major outputs of these institutions, not to mention the fact that the autonomy of bureaucracies also varies between the organizations. In the case of Pakistan, anecdotal evidence shows differences in institutional lending behaviour over time. For example, the ADB continued its lending to Pakistan throughout the 1990s, even as the World Bank and the IMF disengaged their lending operations due to the US-led sanctions that had been imposed on the country, making it difficult for these institutions to gain clearance from their boards. In this section, we will empirically test and compare different IFIs and point out the political economic factors behind their different or similar behaviour. 
In order to analyze the behaviour of different IFIs and to test whether coefficients for a given IFI differ from those of another IFI, we have constructed new explanatory variables from the variables used in Table 1, regression 6. By multiplying each explanatory variable with the dummy variable for each institution, we end up with 44 variables specific to each of the four institutions in combination with each of the eleven explanatory variables. These variables are then taken up one by one, with the rest of the explanatory variables from regression 6 left unchanged, i.e. assuming constant coefficients as before. All in all, 44 different Tobit estimations were carried out to test the significance of the additional term in each case. The estimated coefficient along with the signs of these institution-specific variables show clear differences among IFIs concerning their lending to Pakistan. The signs of the coefficients indicate in which direction the influence of any particular variable on the lending decisions of a specific IFI differs from the influence of the same variable for all IFIs jointly. Table 2 clarifies the exposition by presenting an overview of direction and level of significance of the institution-specific variables.

The overall results clearly show two distinct groups of IFIs, in terms of their lending to Pakistan. It appears that the IDA and ADB, the two more concessional lenders, have almost the same lending preferences, whereas the IBRD and IMF constitute a different group, again with strong similarities.

As opposed to what might have been expected, the IMF and the IBRD, which are most frequently under public criticism for their lending practices, can be shown to be by no means less oriented towards recipient need and merit than the IDA and the ADB. As for recipient need, as measured by per capita income, the IMF and the IBRD even seem to be clearly more responsive, as they show a more strongly negative relationship between the recipient's per capita income and lending. These differences are clearly significant throughout.

At the same time, looking at current account and budget deficits, the IDA and ADB seem to react more strongly on need, i.e. they tend to lend relatively more at times of strong deficits (in particular budget deficits, for current account deficits, there is not much evidence of significant differences). As mentioned before, however, it is difficult to interpret the reaction on deficits merely in terms of recipient need. Alternatively, low deficits may be interpreted as an indication of good policy performance, in which case IMF and IBRD lending decisions could be interpreted as merit based. 
TABLE 2

Tobit Estimated Parameters by IFIs

\begin{tabular}{lcccc}
\hline & IMF & IBRD & IDA & ADB \\
\hline Recipient need & & & & \\
GDPPC & --- & -- & ++ & +++ \\
CurrentAcDef & n.s. & - & n.s. & n.s. \\
BudgetDef & -- & -- & ++ & +++ \\
Recipient merit & & & & \\
GDPg & --- & n.s. & +++ & +++ \\
PolInstab & n.s. & -- & + & +++ \\
Bureaucratic interest & & & & \\
Pk_ed_vp & --- & -- & + & +++ \\
Pk_off & --- & -- & ++ & +++ \\
MultiDt & - & -- & ++ & +++ \\
Bilateral donor interest & & & & \\
USTrade & -- & -- & +++ & +++ \\
JPTrade & --- & - & ++ & +++ \\
dummy01_02 & n.s. & -- & ++ & n.s. \\
\hline
\end{tabular}

Notes: $\quad+++(---)=$ significant positive (negative) at $1 \%$ level; ++ $(--)=$ significant positive (negative) at $5 \%$ level; $+(-)=$ significant positive (negative) at $10 \%$ level; n.s. $=$ non significant. For detailed description of the variables and their sources, see Anwar (2006).

The signs indicate the difference between the effect for each individual IFIs and the effect for all IFIs jointly.

Similarly, the IDA and ADB seem to reward growth more than do the IBRD and the IMF. So far, this has been interpreted as a reaction to promising economic performance, i.e. good (economic) governance. At the same time, good governance in terms of political stability seems to be considered more seriously by the IBRD, while the IDA and ADB tend to reward political instability. This inconsistency in the reaction to the two different governance indicators may raise doubts about the interpretation of the economic growth variable. In fact, while being an indicator of successful 
economic policy, high growth rates also imply that a country becomes increasingly interesting as a partner for trade and investment. Therefore, supporting countries with high growth rates may be in the interests of those major bilateral donors represented on the boards of the different international institutions. We will return to this point below.

Turning to the political economic grounds for lending, the lending record of the IDA and $\mathrm{ADB}$, compared to that of the IBRD and IMF, provides more evidence of such motivations. We observe that both IDA and ADB lending to Pakistan is much more strongly related to Pakistani national bureaucratic power and to the number of Pakistani officers at these institutions, than is IBRD and IMF lending. Our results, showing that the IDA and ADB are more heavily influenced by their respective bureaucracies than the IMF and the IBRD, and that they have been lending money on political economic grounds rather than for development economic reasons, finds further support when we examine the evidence for defensive lending.

There is clearly more evidence for defensive lending from the IDA and the ADB than from the IMF and the IBRD. The former two organizations thus appear to use more important shares of their new credits to ensure the repayment of previous ones. In other words, bureaucrats issue new credits to avoid losing face by acknowledging their creditor's default.

Finally, even the influence of the economic interests of their major shareholder countries, the US and Japan, appears to be much stronger at the IDA and the ADB than at the IMF and the IBRD. Thus, the development of Pakistani trade relations with these two major stakeholder countries has been more relevant for loans from the IDA and ADB. Concerning the political interests of major shareholders, e.g. joining the US-led coalition on war against terror, we observe no such reaction from the IBRD, IMF and ADB. Following this event, the IDA, however, considerably increased its lending to Pakistan. In Table 2, this difference in response to the political objectives of the US as a major shareholder is reflected in the positively significant coefficient for the IDA interaction term with the post September $11^{\text {th }}$ dummy. This reinforces the evidence for interest oriented, rather than economic policy oriented lending from the IDA.

All in all, the comparison of IFIs' lending decisions to Pakistan portrays two distinct groups, whereby the two less concessional lenders, the IMF and IBRD, seem to be driven more strongly by recipient need and merit considerations than the two other lenders, the IDA and ADB. Conversely, decisions at the IDA and the ADB seem to be driven more strongly by bureaucratic and stakeholder economic interests. 
While this result may be rather unexpected, it could be argued that highly concessional lending is more attractive for recipient countries and therefore induces more active lobbying by national bureaucrats in the respective financing institutions. Moreover, as funds include a significant grant component, major shareholders might consider that they should be allowed to at least use these funds in a way that benefits their own economies. Finally, it could be that the IMF and the IBRD are generally under closer international scrutiny by NGOs and academic researchers. As a regional bank, the ADB does not attract as much attention as an international organization with worldwide membership. And the IDA might escape closer scrutiny due to its focus on low-income countries, which could provide some kind of "immunizing" anti-poverty stamp. Closer international scrutiny obviously induces utility maximizing bureaucrats and shareholder countries to be more careful, as there is a higher risk of losing international renown.

However, while these may be plausible arguments, it must of course be kept in mind that our results are based merely on lending to Pakistan. Similar studies with respect to other borrower countries are necessary to assess the robustness of the empirical evidence presented for this particular countrycase.

\section{CONCLUSIONS}

This paper has analyzed the determinants of IFIs' lending decisions to Pakistan based on the example of the World Bank, the IMF and the ADB. While the objectives of responding to recipients' need and rewarding good economic policy appear to play a role in lending decisions, Tobit regression results reveal that the self interest of IFIs' bureaucracies may be more relevant. International bureaucrats exert their power at the executive board of each IFI and favor lending to their respective home economies as well as defensive lending to any country with a serious risk of default. Another set of political economic variables explaining the economic and political interests of the major shareholders of IFIs also turn out to be partially significant. In particular, some evidence can be found for the relevance of Japanese economic interests. US economic interests, however, cannot be shown to play a significant role. Moreover, the available data do not allow us to find any significant influence of bilateral political interests.

At the same time, a comparison among IFIs shows some interesting outcomes. The IBRD and IMF, which find themselves under strict public scrutiny and continuous research interest of economists and political 
scientists, seem to be more careful to avoid a contradiction between official lending objectives and lending decisions. The available evidence suggests that these institutions react more strongly to changes in recipients' need than do two other institutions, the IDA and ADB. In turn, IDA and ADB lending decisions are more responsive to political economic influences than those of the IBRD and IMF, and it seems that both bureaucratic interests and bilateral donor interests play the most important role there.

All in all, using Tobit estimation and various specifications, based on the example of the World Bank, IMF and ADB lending to Pakistan, this paper provides evidence for political economic determinants of multilateral lending. It seems that IFIs, in particular the ADB and the IDA, move away from their originally defined economic lending objectives. Thus, it remains a promising agenda for future research to explore how international donor institutions behave regarding lending decisions to other countries. 


\section{REFERENCES}

Andersen, Thomas Barbebeck, Henrik Hansen and Thomas Markussen (2005), US politics and World Bank IDA-lending. Discussion Paper 0506. Institute of Economics, University of Copenhagen.

Andersen, Thomas Barbebeck, Thomas Herr and Finn Tarp (2006), On US politics and IMF lending. European Economic Review, Volume 50, pp. 1843-1862.

Anwar, Mumtaz (2006), The political economy of international financial institutions (IFIs)' lending to Pakistan. HWWA Discussion Paper 338. http://www.de/Forschung/Publikationen/Discussion_Paper/2006/ 338.pdf.

Asian Development Bank (Various Years), Annual Report.

Barro, Robert J. and Jong-Wha Lee (2002), IMF programmes: Who is chosen and what are the effects? NBER Working Paper No. 8951.

Barro, Robert J. and Jong-Wha Lee (2005), IMF programmes: Who is chosen and what are the effects? Journal of Monetary Economics, Volume 52, pp. 1245-1269.

Berthélemy, Jean-Claude (2006), Bilateral donors' interest vs. Recipients' development motives in aid allocation: Do all donors behave the same? Review of Development Economics, Volume 10, pp. 179-194.

Berthélemy, Jean-Claude and Ariane Tichit (2004), Bilateral donors' aid allocation decision: A three-dimensional panel analysis. International Review of Economics and Finance, Volume 13, pp. 253-274.

Bird, Graham and Dane Rowlands (2001), IMF lending: How is it affected by economic, political and institutional factors? Policy Reform, Volume 4, pp. 243-270.

Birdsall, Nancy, Stijn Claessens and Ishac Diwan (2003), Policy selectivity foregone: Debt and donor behaviour in Africa. World Bank Economic Review, Volume 17, pp. 409-435.

Borcherding, Thomas E. and Portia D. Besocke (2002), The contemporary political economy approach to bureaucracy. Claremont College Working Papers in Economics 2002-06.

Burnside, Craig and David Dollar (2000), Aid, policies and growth. American Economic Review, Volume 90, pp. 847-868. 
Calomiris, Charles W. (2000), When will economics guide IMF and World Bank reforms? Cato Journal, Volume 20, pp. 85-103.

Cline, William R. and Nicholas P. Sargen (1975), Performance criteria and multilateral aid allocation. World Development, Volume 3, pp. 383-391.

Dreher, Axel (2004), A public choice perspective of IMF and World Bank lending and conditionality. Public Choice, Volume 119, pp. 445-464.

Dreher, Axel and Nathan Jensen (2003), Independent actor or agent? An empirical analysis of the impact of US interests on IMF conditions. Leitner Working Paper 2003-04.

Easterly, William (2002), The cartel of good intentions: Problem of bureaucracy in foreign aid. Policy Reform, Volume 5, pp. 223-250.

Easterly, William (2003), The political economy of growth without development: A case study of Pakistan. In: In Search of Prosperity: Analytic Narratives on Economic Growth edited by Dani Rodrik. Princeton: Princeton University Press.

Economist (2001), Bribing allies: The IMF and the World Bank become part of America's anti-terrorist arsenal. The Economist, Volume 360, Issue 8241 (29.09.2001), p. 71.

Fleck, Robert K. and Christopher Kilby (2006), World Bank independence: A model and statistical analysis of US influence. Review of Development Economics, Volume 10, pp. 210-223.

Frey, Bruno S. and Friedrich Schneider (1986), Competing models of international lending activity. Journal of Development Economics, Volume 20, pp. 225-245.

Gang, Ira and James Lehman (1990), New directions or not: AID in Latin America. World Development, Volume 18, pp. 723-732.

Greene, William (2004), Fixed effects and bias due to the incidental parameters problem in the Tobit model. Econometric Reviews, Volume 23, pp. 125-147.

Hasan, Parvez (1998), Pakistan's Economy at the Crossroads: Past Policies and Present Imperatives. Karachi: Oxford University Press.

International Monetary Fund (2004), Direction of Trade Statistics. CDROM.

International Monetary Fund (Various Years), Annual Report. 
International Monetary Fund Independent Evaluation Office (2002), Evaluation of Prolonged Use of IMF Resources, http://www.imf.org/ external/np/ieo/2002/pu/file8.pdf accessed on 17.10.2005.

Kaufmann, Daniel, Aart Kraay and Massimo Mastruzzi (2005), Governance matters IV: Governance indicators for 1996-2004. World Bank Policy Research Working Paper Series No. 3630.

Kilby Christopher (2006), Donor influence in MDBs: The case of the Asian Development Bank. Review of International Organizations, Volume 1, pp. 173-195.

Michaelowa, Katharina (2003), The political economy of the enhanced HIPC-initiative. Public Choice, Volume 114, pp. 461-476.

Moe, Terry M. (1997), The positive theory of public bureaucracy. In Dennis C. Mueller (eds.), Perspectives on Public Choice: A Handbook. Cambridge University Press.

Mosely, Paul, Jane Harrigan and John Toye (1991), Aid and Power: The World Bank and Policy-Based Lending, Volume 1. London, Routledge.

Niskanen, William A. (1994), Bureaucracy and Public Economics. London, Edward Elgar.

OECD/DAC (2005), International Development Statistics Online Database for Aid and Other Resource Flows, http://www1.oecd.org/scripts/cde/ members/DACAuthenticate.asp, accessed on 17.10.2005.

Polity IV Project (2002), Polity IV Dataset version 2002 (p4v2002), http://www.cidcm.umd.edu/inscr/polity, accessed on 17.10.2005.

Raman, B (2000), IMF Drips for Pakistan Economy. South Asia Analysis Group Paper No.167, http://www.saag.org/papers2/paper167.htm, accessed on 17.10.2005.

Rodrik, Dani (2003), Introduction. In: In Search of Prosperity: Analytic Narratives on Economic Growth, ed. Dani Rodrik. Princeton: Princeton University Press.

Stone, Randall W. (2004), The political economy of IMF lending in Africa. American Political Science Review, Volume 98, pp. 577-591.

Trumball, William N. and Howard J. Wall (1994), Estimating aid-allocation criteria with panel data. The Economic Journal, Volume 104, pp. 87682. 
Vaubel, Roland (1991), A public choice view of international organization. In Roland Vaubel and Thomas D. Willett (eds.), The Political Economy of International Organizations: A Public Choice Approach. Boulder: Westview Press.

Willett, Thomas D. (2001), Upping the ante for political economy analysis of the International Financial Institutions. The World Economy, Volume 24, pp. 317-332.

Wintrobe, Ronald (1997), Modern bureaucratic theory. In Dennis C. Mueller (ed.), Perspectives on Public Choice: A Handbook. Cambridge University Press.

World Bank (2004a), http://web.worldbank.org/WBSITE/EXTERNAL/ EXTSITETOOLS/0,,contentMDK:20263942 menuPK:534312 pagePK :98400 piPK:98424 theSitePK:95474,00.html: accessed on 17.10.2005.

World Bank (2004b), The World Bank in Pakistan: Country Brief. September 2004.

World Bank (2004c), World Development Indicators. CD-ROM

World Bank (2004d), Global Development Finance. CD-ROM.

World Bank (Various Years), The World Bank Annual Report, http://wwwwds.worldbank.org/servlet/WDS_IBank_Servlet?all=\&stype=AllWords $\&$ dname $=$ World + Bank+annual+report $\&$ ctitle $=\&$ srcCitation $=\&$ auth $=\&$ rc $=\& \mathrm{ss}=\& \mathrm{dt}=\&$ lang $=\& \mathrm{dr}=\mathrm{range} \& \mathrm{bdt}=\& \mathrm{edt}=\& \mathrm{rno}=\& \mathrm{lno}=\& \mathrm{cno}=\& \mathrm{pid}=\& \mathrm{t}$ no $=\&$ sortby $=D \&$ sortcat $=\mathrm{D} \& \mathrm{psz}=20 \& \mathrm{x}=0 \& \mathrm{y}=0 \& \mathrm{ptype}=\mathrm{advSrch} \& \mathrm{pcont}$ $=$ results $\&$ setID $=7956891 \&$ pno $=1$, accessed on 17.10.2005. 